DOI: 10.2478/aussoc-2020-0001

\title{
Hungarian Nationality Ethnic Minorities Living in Poverty and Social Exclusion in Ukraine
}

\author{
Ibolya CZIBERE \\ University of Debrecen, Hungary \\ czibere.ibolya@arts.unideb.hu \\ Noémi LONCSÁK ${ }^{1}$ \\ University of Debrecen, Hungary \\ loncsak.noemi@arts.unideb.hu
}

\begin{abstract}
The purpose of the article is to give an overall description of the situation of Hungarian minority households with children in Ukrainian villages. The region is a marginal area both economically and geographically, being in a peripheral position with little attention falling upon it and even less of the development sources. Furthermore, there is a lack of information on welfare benefits, and no direct statistical data are available on the characteristics of the social policy system.

As for the total lack of prior statistics on poverty, this essay is meant to be exploratory to show the area's poverty features, focusing on the children. By the use of combined data collection, including quantitative and qualitative techniques, we gained information by questionnaire surveys of about 253 children in 139 households. There were carried out 23 exploratory interviews as well. The core of our analysis is the specific labour market situation, the earning opportunities, and forms of employment that provide for livelihoods for the households with children. Besides the backwardness of the area studied in the research, the strategies and life situations that characterize the Transcarpathian Hungarians are also presented, which are beyond the known European forms of poverty.
\end{abstract}

Keywords: Transcarpathian Hungarians, households with children, poverty, deprivation, job market, income acquisition, atypical work forms

\section{Introduction}

In our study, we explore the situation of minority Hungarian households with children in Ukrainian villages, primarily through the characteristics of the poverty and the exclusion of the families living there. According to the most recent census

1 EFOP3.6.3-VEKOP-16-2017-00007 - Young Researchers for Talent - Supporting career in research activities in higher education. 
data available in Ukraine (2001), the number of Hungarians living there is 151,500, thus being the second largest minority group in the country (Molnár-Molnár 2005). The newest available SUMMA 2017 survey (demographic survey of Transcarpathian Hungarians) estimates the Hungarian population to be 131,000, which indicates a population loss of $13.7 \%$ in the region. The majority (73.8\%) live at a distance of up to 20 kilometres from the border with Hungary (Gyémánt 2011). The majority of the Hungarian population of the Transcarpathia region lives in villages (63.6\%), while, for example, the Russian minority communities live predominantly in urban areas (Braun et al. 2010). Educational levels have improved since 2001, and Hungarian institutions of higher education in Transcarpathia have a huge role in that. Based on SUMMA 2017 data, $16 \%$ of the population has at least a bachelor's degree, while the percentage of those not finishing elementary school is under 1\% (Tátrai et al. 2018). In the area inhabited by Hungarians, the only livelihood insurance sector is agriculture. One of the most important reasons for this is that the large industrial companies have gone bankrupt and, as a result, many people moved back to the villages (Baranyi-Balcsók 2004). In some Hungarian-populated settlements, this could be up to 100 percent. The peripheral labour market position has an adverse impact on the employment-generated income that can be obtained locally (Sik 2015). The population of the settlements in such a situation is forced to keep up themselves and their families from illegal work. Safe livelihood in many cases is provided by the proximity of the Hungarian border (Gyémánt 2011).

Viewed from the capital, the region is a marginal area both economically and geographically, being in a peripheral position with little attention falling upon it and even less of the development sources. In recent years, the acceptance of work immigration has increased among the Hungarians; this strategy plays a significant role in livelihood security. At the same time, a wide range of livelihood strategies has emerged at the crossroads of legal and illegal, formal and informal solutions (Kovály et al. 2017). According to The World Factbook released by the Central Intelligence Agency (2010), 24.1 percent of Ukraine's population lives below the poverty line, but in this aspect detailed data are not available in the country's statistics. Also, there is a lack of information on welfare benefits, and no direct statistical data are available on the characteristics of the social policy system.

Transcarpathia is the poorest area of the Carpathian Basin; it is in a marginal position compared to Ukraine as a whole. In terms of standard of living, according to information provided by the Bureau of Statistics of Ukraine, in 2012, 22.3 percent of the population lived below the established pension minimum of 1,042.42 hryvnia (UAH) in Subcarpathia. The GDP fell by 7\% in 2014 and by more than 10\% in 2015 . Food prices have multiplied, while wages and pensions have increased by only $8-10 \%$. Inflation was enormous: $24.9 \%$ in $2014,43 \%$ in 2015 , and $12 \%$ in 2016 . In Subcarpathia, the average wages were significantly lower than the Ukrainian average wages. According to the Ukrainian Bureau of Statistics, the average monthly salary 
in Subcarpathia on 1 January 2016 was 3,419 hryvnia (UAH), while the Ukrainian average was 4,362 hryvnia (UAH) (Kovály et al. 2017).

In the absence of recent data, the regional characteristics of the area can be inferred from the findings of the Carpathian Panel 2007. This survey was carried out by Eleonóra Molnár and Ildikó Orosz in Transcarpathia on a sample of 350 persons, using a multistage random sampling method at household level. According to their results, the average monthly salary of the active age employees is $767 \mathrm{UAH}$, while the inactive persons earn 446 UAH (Molnár-Orosz 2007).

The officially estimated unemployment rate in Transcarpathia was $10.2 \%$ in 2017 , which is similar to the Ukrainian average (9.6\%). At the same time, analysts consider that hidden unemployment is the most serious problem in both Transcarpathia and Ukraine. According to the most conservative estimates, the unemployment rate should be three to four times higher, i.e. about one in four. A value of $30-40 \%$ most closely reflects reality (Kovály et al. 2017).

The question of language use is a further disadvantage, basically defining the living conditions of the Hungarians in Ukraine. In Ukraine, the Ukrainian language is the language of official affairs in Hungarian-speaking areas as well. As the majority of the Hungarian minority does not speak the Ukrainian language, there is an insurmountable difficulty in solving the simplest everyday situations, let alone office affairs, employment, and healthcare or school affairs.

The infrastructural supply of the Hungarians of Transcarpathia is extremely incomplete. The construction of a fixed natural gas system was made back in the Soviet era, but its development stopped after the regime change. The later developments were concentrated on Ukrainian villages, so there are also settlements covered by our research where there is still no natural gas. The drinking water system is not built at all in $77 \%$ of the settlements, and only $13 \%$ can be considered completely solved. Sewerage is even worse: $82 \%$ of the respondents do not have access to a built network. Refuse collection can be considered to be solved for 65 percent, and for 25 percent it is completely missing (Darcsi 2008).

During the 2001 census in Transcarpathia, 1.1 percent of the population $(14,004)$ declared themselves as having Roma ethnicity. Two-thirds of them speak Hungarian as their mother tongue, and in the case of rural Gypsies this exceeds even 80 percent. The proportion of the unemployed is extremely high among them as well. Geographically speaking, they live in specific parts of villages or towns, mostly in "camps” (Gypsy settlements), in segregated conditions, away from centres and the otherwise scarcely accessible institutional services. The infrastructural services of their own settlements do not reach them, so there is usually no fixed water supply, gas supply, or sewerage where all these are otherwise available in the given settlement (Braun et al. 2010). Local Gypsy groups differentiate their groups according to their self-identified categories, which is accepted and used by the local non-Gypsy population as well. According to these, three groups within the local 
Gypsy population can be identified as follows: the uppermost layer is the uci, i.e. the wealthy, rich group of Gypsies; the middle layer is the váci, the adobe bricklayer group, including traditional Gypsy craftsmen and other physical workers; the lowest and poorest layer is the döci group of carrion eaters - they are the ones who consume even the bodies of the fallen animals (Loncsák 2015).

\section{The Complexity of Poverty}

The constellation of poverty and wealth is at the core of interpreting and understanding the distribution of inequalities in a society and the different advantages and disadvantages that stem from them (Csepeli et al. 1992). Traditional societies relied on a deterministic interpretation of this dichotomy; to quote the authors: "it was dependent on assuming societal causes" (Csepeli et al. 1992: 21). In contrast, modern societies which put emphasis on individual performance as well as on individual freedom and responsibility have shifted towards a focus on individual causes for explaining privileged versus disadvantaged positions in society. Individual lives are increasingly determined by key prerequisites to a good life. Life chances are more and more dependent on accumulated knowledge, cultural and social capital. Childhood is the most dominant life stage in this, and one of the most impactful factors are interactions between parental and social investments during childhood (Esping-Andersen 2008).

Scholars have categorized and interpreted the complex phenomenon of poverty in multiple ways, viewing it as a social fact that cannot be seen solely as an objective state; it is also a social construction created by members of a given community. Any concept that has ever been established to describe and explain poverty has its own social history, embedded in particular political, economic, and social processes that were present at its inception. Thus, some researchers, dependent on their leanings, have used specific paradigms to support their ideologies (Silver 1996). At the same time, poverty and its manifestations are difficult to interpret outside of a given social environment. We could argue that concepts and devised paradigms to explain poverty are largely shaped by the political culture, social structure, dominant ideology, and social policies of a given society. Therefore, it is a strenuous job to provide an accurate definition which is demonstrated by the arguments above. As a result, it is not extraordinary to have different concepts of poverty simultaneously. Different definitions of poverty lead to distinct versions of poverty to discuss. This does not mean that we do not have - even if not comprehensive - scientific theories regarding poverty.

To mention a sole author, Szalai (2002) distinguishes between temporary and longterm poverty by categorizing the poor into two categories: those poor in income, who are struggling to earn a decent living, and the truly underprivileged, i.e. the marginalized 
and excluded, living in absolute poverty. The poor in income group exists because of "simple" distribution issues; either because incomes in certain segments of the labour force fall under the level that is necessary for everyday sustenance or because incomes lose some of their value. This group of the poor still belongs to the majority of society because once their income increases they can restabilize their position and return to the spheres ruled by the majority. The truly underprivileged and excluded are in a completely different situation as they have either never had those ties to society or they have lost them, and so they cannot reintegrate themselves into society. What the socially excluded have in common is a long history of poverty, potentially spanning decades, and the extent of their poverty is extreme and absolute (Szalai 2002).

Various discourses about poverty are generated by varying beliefs regarding the nature and extent of poverty as well as the sources of social inequalities and longterm unemployment. These tend to follow modernization patterns. Variations in the definitions and social histories of poverty also lead to methodological deviations in the indicators and measurement of the phenomenon in each country as well as to different practices in social policy and different philosophical principles behind them. As a result, guided by varying social realities, countries can have not only a distinct interpretation and measurement of poverty but different terms to refer to it as well. This study explores types of poverty, their causes and correlations among households with children in Hungarian villages in Transcarpathia. ${ }^{2}$

In our analysis, due to the general and extreme levels of poverty experienced by households with children in the region, we were unable to apply relative poverty measurement techniques. Therefore, the results of our research are presented on the basis of the deprivation characteristics of the examined population using the European Union's At Risk of Poverty or Social Exclusion (AROPE) indicator system.

\section{Research Methodology}

In our exploratory research, we examined the quality of life, the forms of poverty and social exclusion of households with children in villages inhabited by Hungarians. For this, we used both quantitative and qualitative data survey tools. The quantitative data survey methodology was based on the joint application of two questionnaires. ${ }^{3}$ The first questionnaire asked about the structure, income, employment opportunities, housing situation, social support systems, and subjective well-being of households. With the second questionnaire, whose purpose was to collect data about children,

2 In this study, we rely on our own works published in Hungarian: Czibere-Loncsák-Gégény (ed.) 2017; Czibere-Loncsák 2018.

3 We relied on the classic questionnaire used in research studies on children's poverty and children's chances, developed by the Hungarian Children's Chances Research Group of the Hungarian Academy of Sciences, and we adapted and supplemented it with questions related to the area. 
we measured the fulfilment of the physical needs of children (nutrition, clothing, developmental toys and devices, etc.), their state of health, their physical and mental state of development, the chances of access to kindergarten care, school performance, services available in schools, and parental aspirations for children's future and their further education. A separate questionnaire was completed for each child in the households visited. The presentation of children's poverty is not a purpose of our present study. The qualitative research supplemented the results of questionnaire surveys, in which 23 interviews were made with Gypsies and nonGypsies. Data collection took place in 2016.

\section{Sampling}

During the sampling process, we encountered methodological difficulties due to the almost complete lack of regional and local population data. Population and settlement-level data for the surveyed area and the selected settlements were available only from the 2001 census, and there were no household or age-group distributions or other information beyond settlement size. During the selection of settlements, we kept in mind that the settlements were inhabited by Hungarians to a great extent (above 50 percent) and, secondly, that there were three settlements that represented a typical category in the region. Apart from the central town of the region (Beregovo), the villages play a decisive role. The villages fall into three types according to the number of inhabitants: those with 500 to 1,000 , those with 1,500 to 2,000, and those with about 3,000 inhabitants. Research sites were selected based on these categories.

Since we did not have reliable population data, we could not determine exactly how many polls would be required in the selected settlements or basically what the population was in the settlement or what the number of households with children would be, and so we visited the region's key intelligence expert on local issues, who had a "volunteer mediator" role between the local population and the Ukrainian authorities, institutions, and providers in the three selected settlements and acted as their personal agent for managing their official affairs. For this reason, this person had important information about villagers and households with children. Due to the lack of municipal statistical data, the questionnaire data collection would not have been possible without our local assistant's information in this area. In each of the three settlements, we sought out homes with children based on street plans prepared

"The mediator carries out the task that the local government or its organs in European countries would have. In everyday life, this means that the mediator speaks the official language, knows and understands the rights and laws, and occupied an official position during the Soviet era, so he knows the system, and the system knows him. He provides people with information about the benefits and entitlements that are available to them 'on a courtesy basis' as well as does the submitting of official applications and documents for a minimum remuneration. He does, in one person, the handling of official affairs, not just in the field of social care, for the people living in the settlement and some surrounding settlements" (Loncsák 2015 - authors' translation). 
by our informant. In the majority of the cases, the respondent was the mother or the closest adult relative of the children who was in the house when we were there. For each child in the household, a separate questionnaire was also completed. Data were collected from 139 households and 253 children altogether (Table 1).

Table 1. Number of questionnaires per settlement

\begin{tabular}{lcccc}
\hline Settlement & $\begin{array}{c}\text { Settlement 1 } \\
\mathbf{3 , 1 4 7} \\
\text { inhabitants }\end{array}$ & $\begin{array}{c}\text { Settlement 2 } \\
\mathbf{1 , 5 0 2} \\
\text { inhabitants }\end{array}$ & $\begin{array}{c}\text { Settlement 3 } \\
\mathbf{7 5 2} \\
\text { inhabitants }\end{array}$ & Total \\
\hline $\begin{array}{l}\text { Household } \\
\text { questionnaires }\end{array}$ & 96 & 25 & 18 & 139 \\
$\begin{array}{l}\text { Children } \\
\text { questionnaires }\end{array}$ & 181 & 40 & 32 & 253 \\
Total & 277 & 65 & 50 & 392 \\
\hline & & \multicolumn{3}{c}{ Source: Data collected by the authors }
\end{tabular}

According to the quantitative results, primary education can be considered as the highest (29.4\%) level of educational attainment in almost one third of the households, but the proportion of upper secondary education - but not yet graduate - $(45.3 \%)$ is outstandingly high, and, within this, the rate of secondary vocational education is similarly high (32.4\%). Higher education is present only in 8.6 percent of the households. In almost half of the households, we found family members with at least secondary education, but the number of graduates is extremely low. We presupposed that the level of educational attainment would have an impact on poverty, but this linkage did not prove effective due to the general poverty of households in the settlements surveyed.

The qualitative data collection was done based on expert sampling. The 23 exploratory interviews took place in one single selected settlement, 3 of the interviews were made with local decision makers (church leader, volunteer mediator, a civilian supporter of Gypsy families), and 20 with people affected by poverty. The interviewees were selected on the basis of two main criteria. On the one hand, we looked for households and families where the breadwinner did not have a secure income and, on the other hand, we interviewed people who self-identified as poor. This secondary criterion ultimately proved to be a more important selection factor on the spot than a secure income because the inhabitants of the settlement live in such a deep poverty that the majority of the population do not have a secure income, and so almost the same level of extremely low standard of living is present among the people living there. Out of our interviewees, 10 were of Gypsy ${ }^{5}$ and 10 of non-Gypsy origin. The interviews supported, supplemented, or provided a more detailed explanation of the results of our questionnaire survey.

$5 \quad$ We considered Gypsies those who were held as such by the mediator. 


\section{The Living Standard and Deprivation Features of Households}

\section{The Structure of Cohabitations}

In the households that were interviewed, the three-to-six-person cohabitation is typical, while households with two persons are not so typical. In the majority of the 139 households, one $(45.3 \%)$ or two children (33.1\%) are raised, and in one in five households there are three or more children.

As for the features of the family structure, more than half of the family members live in an extended family (53.6\%), i.e. among the household members living together there are other adult family members besides the children and their parents. These are forced coexistences, where parents allow their adult children to continue living with their own family after being married.

\section{Housing Conditions of the Households}

Bad housing conditions and housing poverty can lead to a persistent stagnation of the situation of people living in poverty and is one of the strongest factors of passing on poverty. That was the reason we studied the housing conditions of the families visited, in which we asked about the furnishing, comfort level, the physical condition of the apartments, and the quality of the living environment. According to our results, the comfort of families with children is extremely low. There is a separate kitchen in almost every building, but only 64 percent of households have their own bathroom, and there is a flush toilet in only every second house (47 percent). Drinking water supply is critical. Only $18.7 \%$ of households have access to water supply, while the rest of the households needs to solve the problem of water access themselves (the drinking water network is not properly built in the Hungarian villages examined in our research). This also means that four-fifths of households use non-drinking water for their cooking, cleaning, or washing needs. Gypsies live in segregated, estate-like conditions. They own their apartments, part of which is brick-built with one or more rooms built after the great flood of 2001. The houses are damp, mouldy, the plaster is falling off, and the doors and the insulation are missing. Typically, there is no bathroom or flush toilet. The lack of utilities is solved with different techniques. According to their statements, electricity is the most important thing, its payment being a primary need. The problem of the heating and of drinking water can be easily solved by alternative methods. Firewood is picked from the forest, while drinking water comes from drilled wells or asked for from residents on the street if there happens to be no water in their own well. 


\section{Deprivation Features}

When designing our research, we wanted to measure the relative poverty level (based on income level) among households with children, and we wanted to make a difference between the poor and the non-poor households according to the dimensions examined. However, because of the circumstances described above, mainly due to the generally widespread poverty, we could not measure the poverty level by the income level, and, consequently, we could not identify separate groups. Therefore, we decided to distinguish between groups of households with children in the three settlements on the basis of consumption poverty (deprivation).

The Europe 2020 Strategy Indicators (Európai Bizottság 2010) identify the broadest possible range of those at the risk of poverty and social exclusion. The complex poverty and exclusion index (AROPE - At Risk of Poverty or Social Exclusion) defined that those people are exposed to the risk who live in either income-related poverty or in poor or low-skilled households (work-related poverty) or people with severe financial deprivation (they suffer the lack of at least four out of nine consumer items for financial reasons). Accordingly, $8.1 \%$ of the total population in the European Union (EU) is severely deprived (reference year: 2014). Their highest rate is in Bulgaria (34.2\%) and the lowest in Sweden (0.7\%) (KSH 2016). In the EU, the biggest difficulty for the population is to cover unexpected expenses $(37.3 \%)$ or a one week's rest (34.3\%). In Hungary, $16.2 \%$ of the total population - twice the EU average - is severely deprived (reference year: 2015) (KSH 2016). Similarly to the EU results, the biggest difficulty for the Hungarian population is to cover unexpected expenses and to finance a one week's vacation, but, concerning half of the population, their rates are much higher than the EU rates in both cases. No data had been collected for these contexts in the area under our review, so there was no prior information on the proportion of people living in risk of poverty and exclusion or on the status of those affected.

Households in financial deprivation were identified by the deprivation index formed from the variables in the database. Households (and those living in them) were considered deprived if they were affected by at least three of the nine dimensions of financial deprivation (AROPE - At Risk of Poverty or Social Exclusion), and they were considered seriously deprived if they were affected by at least four of the nine dimensions:

1. they have arrears of loan repayment or any payment in relation to their home;

2. lack of adequate heating of their dwelling;

3. lack of cover for unexpected expenditure;

4. failure to consume meat, fish, or equivalent nutrition every two days;

5. lack of yearly one-week out-of-home holiday stay;

6. not having a car for financial reasons;

7. not having a washing machine for financial reasons; 
8. not having a colour TV for financial reasons;

9. not having a telephone for financial reasons.

Depending on the deprivation index, half of the households with children were deprived, and almost two-thirds of the deprived (69.6\%) were seriously deprived. Considering all households, 34.8 percent of families are seriously deprived, indicating extremely critical levels of poverty.

In $52 \%$ of deprived and seriously deprived households, there is no active workforce with declared income; for them, even the most unpredictable occasional work and the social benefits for children are decisive. Families in such circumstances live in complete insecurity and financial vulnerability, most of them lacking any savings $(88.5 \%)$. In addition to the poverty of consumption, there was considerable financial uncertainty for them. In the case of nearly two-thirds of the respondents, it happened in the past year that they had spent all their money before the end of the month. Poor financial situation also entails indebtedness. When examining the indebtedness of households with children, we asked whether they had any debt and, if so, where it came from. Indebtedness affects 26.6 percent of households with children. The debt structure has a specific composition: it is primarily determined by the complexity of the consumption structure of the households surveyed. Debtors mostly fall into 1 to 3 categories, most notably due to gas or electricity billing, shopping debts, and family/friend/acquaintance debts.

Based on the responses from the supplementary interviews, we identified three categories of income in the households: those who live only on aid, those who live mostly on aid, and those who live only on occasional work. For those who live only on aid, there are more factors that make their livelihoods more difficult: e.g. persistent illnesses, large number of children, steady lender's loans, illiteracy, and poor housing conditions. This category appeared only among our Gypsy respondents. The category of people who live only on occasional work is common to both groups in that they do not have adequate housing conditions either, but the Gypsies included in this category also have debts towards the usurer. In families with occasional work and aid, aid (primarily maternity allowance for children) provides some kind of constant security. Upon payment, this is usually taken directly to the village store as they have been buying on credit for a whole month. In this system, the shopkeeper keeps track of the amount of the aid and that of the expected income according to which shopping can be done in advance in a given month.

Well, it's good for us, here is this supermarket, Ildikó runs it, and I get everything there on credit, and then when the child benefit arrives, we pay it back. It's always okay in the end, and now she trusts us; even as much as 600 or 700 hryvnias are collected, and then, when the child benefit arrives, we give it back, and then if something is still missing or we need soap or washing liquid, then we go and she adds it to the list. It's good for her as well as for us; 
there is more of all this in the shop, she wouldn't sell all in one, and so she gives it to us, and you never forget to give the money. (a non-Gypsy woman with 6 children, day-labourer)

The interviews also revealed that the structure of expenditures is relatively uniform, the main feature of which is shifting consumption to meet the physical needs. Most of the interviewees' money is spent on food, and there are also those who have their medicines among their major expenses, or they spend their money on clothing if there is any left.

Well, on food and clothes if there is any [money] left; if nothing is left, then what is possible to go without, we go without. The food is important here, the clothes are okay what they have. The food, it's necessary to buy it, everybody knows this. (a non-Gypsy woman with 3 children, day-labourer)

According to our results, non-Gypsy respondents can devote more to clothing, and in their group we find more families who invest in a household economy, do livestock farming to improve their livelihoods, or have started cultivating plants. We also asked our interviewees what they could afford to spend the most on. Among the Gypsy respondents, there were also some who could not afford even the onetime hot meal a day.

Not so much, it happens that I don't eat for days, just this and that... Well, I make these simple soups, and I have just bought in Rózsika's shop this ... it's cheap. Well, dear, I can do what I can do, not much. (Gypsy woman with 2 children, housewife)

It appears with both Gypsy and non-Gypsy respondents that they cannot eat meat for 2 to 3 days.

When we have money, we eat, when we don't have, we don't eat. (a Gypsy woman with 3 children, day-labourer)

Well, sometimes, not always, we don't have money for food; we are used to this; when we don't have money, we don't have it. This is how we are used to it, but we eat hot meal every day. (a non-Gypsy woman with 1 child, daylabourer)

Those who cannot afford either food or clothing are lacking durable consumer goods as well; however, in homes where there was electricity, there was always a TV set. Among the respondents, a new warm coat for winter, the fridge, the freezer, the stove, and in many cases seasonal footwear were also considered a luxury item 
and also a shortage, which was equally characteristic of our Gypsy and non-Gypsy interviewees. Around festive days, gifts cannot be afforded by the interviewed families; we found interviewees who take this as a natural situation, but there were also persons who were ashamed of this.

Well, as for presents, we can't afford them [smiling, showing pity], especially not in the winter, for Christmas. Last year again, he came home [the breadwinner man, who works farther away, not in the village], like always by Christmas time, but he can never bring money. Then, if he finds something to do, we are happy if we have enough for food every day. (non-Gypsy woman with 3 children, housewife)

We don't give presents, we eat; we try to arrange that we can eat enough at that time. There are also Gypsies here who don't go to Moscow, they live here, weaving baskets, they work a lot in winter so that they have enough to eat. (non-Gypsy man, with 1 child, day-labourer)

\section{The Labour Market Situation: Opportunities and Forms of Earning Income}

\section{Forms and Characteristics of Doing Work in Households with Children}

\section{Officially Registered Work}

What determines the wealth of households is how jobs are distributed among the households of the region, that is, their labour intensity. Individual labour market activities have different welfare implications. The magnitude of these welfare impacts depends heavily on the distribution of existing jobs among the households. It is very common that the basic unit of welfare indicators is not the individual but the household, regardless of the fact that the labour market statistics generally relate to individuals. Households with very low labour intensity belong to the most vulnerable groups in society. As they are less integrated into the labour market, their earning capacity is the worst, and therefore they live in poverty or at risk of poverty.

In order to explore the employment situation and labour market characteristics of the examined families with children and households, we asked the active members of the households whether they were currently working or whether they had worked in the past 12 months, and, if so, how much time they had spent working. On the basis of the answers, we created a work intensity scale. ${ }^{6}$ The labour intensity indicator

6 In order to determine the labour intensity of households, the working time of all workingaged people in the households (18-59 years) was compared for the last 12 months with the 
may range between 0 and 1, in which 0 means that no one worked in the surveyed household during the period under review, and 1 means that everyone worked full time in the whole reference year. Households in which working-age adults worked in the reference year less than 20 percent of their total labour potential (i.e. a labour intensity value of up to 0.2 ) were considered to be very low in work intensity.

In order to determine the extent of the presence on the labour market, we considered the activities performed as an employed person (full-time employees) and those performed as an occasional worker as separate categories. In the following, we describe the results obtained: we present separately the primary labour market participation and then the results including the occasional work as well. Our results refer to the working time of people aged between 18 and 59; however, we also had cases of below 18- and over 59-year-old family breadwinners.

The data show that almost half of the active adult family members of households with children were not present at all in the primary job market during the year preceding the questionnaire (Table 2). Households with the highest work intensity, whose members worked almost all year long, but at least two-thirds of the year, account for only 15.5 percent of the households surveyed.

Table 2. Labour intensity of households (without casual work)

\begin{tabular}{lcc}
\hline $\begin{array}{l}\text { Labour intensity } \\
\text { indicator }\end{array}$ & Number of households & $\%$ \\
\hline 0 & 55 & 47.4 \\
\hline $0.1-0.33$ & 10 & 8.6 \\
\hline $0.34-0.66$ & 33 & 28.4 \\
\hline $0.67-1$ & 18 & 15.5 \\
\hline Total & 116 & 100 \\
\hline
\end{tabular}

Source: data collected by the authors

It is clear from the detailed breakdown that in terms of labour intensity there are two large groups of people living in the examined Transcarpathian Hungarian villages. Active-age adult members of one group have no relationship with the primary job market (47.4\%), while members of the other group worked just in half of the year (0.5 labour intensity, 21.9\%).

\section{Occasional Work}

If we take into consideration the occasional work as well, the labour intensity of the households and the amount of time spent working increase. Thus, the labour market of the region is significantly determined by the world of occasional work. According to the results of Table 3, the number of households with zero work intensity drops by 
more than half (from $47.4 \%$ to $22.0 \%$ ), and the number of households with second and third thirds increases. Particularly noticeable is the significant increase in the ratio of households in the highest third, which has more than doubled compared to the previous situation (from $15.5 \%$ to $36.4 \%$ ). In other words, with the involvement of occasional work, the former labour market characteristics change. Considering occasional work, one of the dominant groups of households includes households with a working intensity of 0.5 (working for at least half a year) (26.3\%), the other significant group being 1.0, i.e. full-time employed households throughout the entire year. The third determining group continues to be represented by the zero intensity households (19\%). If we add the very low work intensity (up to 0.2 ) households to the latter, then one-quarter of the households surveyed are still excluded from the labour market, having no labour-based income.

Table 3. Labour intensity of households (including casual work)

\begin{tabular}{lcc}
\hline Labour intensity & Number of households & $\%$ \\
\hline 0 & 26 & 22.0 \\
\hline $0.1-0.33$ & 10 & 8.5 \\
\hline $0.34-0.66$ & 39 & 33.1 \\
\hline $0.67-1$ & 43 & 36.4 \\
\hline Total & 118 & 100.0 \\
\hline
\end{tabular}

Source: data collected by the authors

According to the results, there is very low employment in the households surveyed, and the distribution of work among households is very uneven. Although comparative statistics are not available in Ukraine, according to Eurostat's 2016 results, the proportion of low work intensity population in Hungary in 2015 was approximately 10 percent (in the previous years, it exceeded 12 percent), which is very high compared to the results of the Visegrád countries (below 8 percent in all countries) (EUROSTAT 2016). Compared to this, the number of households with low labour intensity is critically high in the Hungarian villages in Transcarpathia. This is also a serious problem as the local welfare system or the lack of it cannot compensate for the resulting impoverishment processes.

\section{Commuting and Mobility}

In order to explore commuting and mobility opportunities as well as social relationships, we investigated how far workers travel from their home for work opportunities. According to the results, adult members of households with children are not mobile: they live in a closed system of villages and/or in nearby villages. Most of them work in their own village, but, as we have seen before, a very large part of the households do not have a working family member, so commuting is 
naturally absent in their case. Individuals working in nearby villages or small towns do not move away from their village significantly either, and this does not allow them to expand their relationship capital or to improve the quality of their social relationships. This situation affects a very high percentage of the households surveyed, almost 70 percent. To a lesser extent, though, there occurs also the phenomenon of employment abroad: in 15 percent of the households with children, there is a family member working abroad. First of all, Russia and Hungary are the two target countries for labour migration.

The lack of labour market mobility functions also as a kind of self-segregation in the examined region, as a result of which the phenomenon of isolation of a disadvantaged minority group takes place. Families living here are not motivated by the lack of technological development or the lack of production capacity for migration, either. Regarding our question as to whether respondents like to live here or plan to move away, they almost unanimously answered that they are very keen on living in their village and almost no one plans to move out.

Ethnic and territorial segregation significantly hinders the establishment of labour market relationships. As there is an insufficient number of external labour market links (lacking bridge-like relationships) which could bring new job opportunities in the families of the respondents, the relationships within their own communities is intensified. This situation preserves poverty and increases the social distance from better-off communities.

According to our interviews with decision makers, the atypical forms of employment in the region are decisive. Although they are irregular, they can be wellorganized day by day. Most of these people can join the day-to-day work, which is the main form of employment in the region, and it characterizes urban settlements and villages as well. This type of work appears in two forms: local and foreign day labour. Local day labour is mainly focused on the given settlements and the surrounding villages, involving low wages and day-to-day physical work, and they mean mostly agricultural auxiliary work. Regarding day labour abroad, two target countries are dominant: Hungary and Russia. Work in these countries means mainly construction-related auxiliary work. Due to the proximity of the border, there are other atypical, often illegal, work types such as the transport of passengers across the border, smuggling of fuel and goods, or smuggling of stimulant goods (e.g. cigarettes). The responses, however, show that these risky affairs do not bring financial security or a steady income either, and the risk of getting caught is very high.

The most serious problem of our interviewees is the lack of local job opportunities. One consequence of this is the migration of people (labour migration). In the families, mostly men are forced to look for work opportunities in another country. According to our interviewees, at the beginning of the process, this means mostly the commuting of men between the family and the remote workplace, but later on, in many cases, it also involves permanent resettlement. 
Typical activities among the respondents are traditional handicrafts for both Gypsies and non-Gypsies. Such a typical work for gypsies is basket weaving, sundried brick-making, eaves making, and sewing for non-Gypsies. A separate incomegenerating technique has emerged for the event when they cannot go for day labour, and there is no other casual work in the neighborhood either: in such days, they collect metal pieces from landfills and take them to the nearby urban centre.

The poorer gypsies are the basket weavers, the brick-makers, there are the day labourers, and others who don't do work; we know which of them are more skilled at land work, which of them move better; they go to collect corn or potatoes, they collect cucumbers here in Vári, and go to do planting. And then, when the time is over, when there is nothing to collect in the fields, no agricultural work, then they go to the landfill and then look for metal ... these gypsies go there and collect the metal pieces, they dig into the ground, they like to disappear there in the holes. (decision maker)

There are also situations when non-Gypsies do metal collection as well, men and women alike. This is a hard physical work, but there are families who have only this type of work as their only chance to survive. Other sources of income among the poor include the sale of seasonal products: they mentioned nuts, mushrooms, and wood in this respect. There are also other special ways of making money, one of which is to share child allowance between parents even if one of the parents is no longer living with the family. This is the case, for example, when parents do not live together and the father not only pays no alimony but feels he is entitled to receive his share of the child's subsidies from the mother every month. And the mother in question does not complain about it, saying "they are his children too" (a Gypsy woman with 9 children, housewife).

It is also a special livelihood business that some people build wells somewhere in a public area, making use of the lack of drinking water in the neighbourhood, or rather of the lack of wells, and then ask money from the poor in exchange for water and, although it is a minimal amount, it provides them with constant earnings.

As another income source, we should note the usury system, which basically determines the life of those with Gypsy origin, but it also appears among the nonGypsy population. Among our subjects, there are some who are currently in debt, and there are some who are always in debt. Those who work abroad in the summer usually do not undertake any work in their settlement or in its neighbourhood during the winter, and so they are forced to indebtedness in order for their family not to starve. Then, in the summer, when they are back to work, they repay the loan. However, there were also people who could not afford to pay anything above the interest, as generally 20 to 30 or even 100 percent interest is charged on the loans. 
Well, how long does it last what we earn? Well, it happens that we earn a lot, lots of money, and it happens we earn nothing... With what we earn, when we come back home, we buy food for the winter, as long as it lasts, then we run out of all our food, then we take loans and we again go to Moscow in the summer, and though he takes interest on it, in the summer we give it all back; maybe they give it for 25 or $30[\%]$. (man of Roma origin with 1 child, day labourer)

If they cannot pay the loan back, then another amount will be accumulated again the next year, which they can only partially repay, creating an irreversible process of indebtedness from which they cannot quit. To my question why they still take it, a poor Roma-born responded with the following:

Not to take it? And then they would be starving? If we didn't take it, there would be nothing to live on when there is no money. Of course, they don't mind, those who give it... They are not interested from where it will be paid back, and those don't mind either who take it that they will have to give back more than half of it on top; the only important thing is that they get the money because there is no money for food! You need to think, only get as much as you can pay back. Month after month you only work so that you can eat. (man of Roma origin with 1 child, day labourer)

According to gender, there are very significant differences in labour market participation. Women are housewives, the wage-earning work is done almost exclusively by men, and with several interviewees we saw that, in addition to men, adolescents or older children too had some income-earning activity. We also encountered a family where the child was the bread-winner in the family. These children are mostly the children of semi-literate or illiterate parents who, even if they are very talented, are forced to work for the family rather than do their studies. Child labour is not an unusual phenomenon in the area, being a general and accepted problem, especially for older children. Most of the work they do is also day labour.

My problem was not that I would not go on to study, I did want to, I didn't go because when I left school, being 18 years old, my mum and dad were not able to work, they were both ill, so I was the only bread-winner. If I had gone to study, they would not have given me money, they would not have had enough to live on, I would not have been able to support my mum and dad [about to start crying]. This was the reason I could not go on with schools! No money to pay my costs, no money to live on, and I would not have been at home, either. I had no other way than to choose work... (non-Gypsy man with 1 child, day labourer) 
Men form a much more mobile social group than women, who are stuck in housework and work around the house and in the village. Their roles are complemented by managing everyday life situations. This separated lifestyle for both genders - beyond physical burdens - also involves serious mental and partnership problems, which, according to the interviews, often result in the families being completely disrupted.

... the men go away for seasonal work with a work visa, they go further away from their families, for a month at a time. And so, they also get alienated from their families, and many families are broken as the father is elsewhere, the mother is at home with the children, and the money he earns needs to be carefully spent by the mother and the family so they can support themselves. (volunteer mediator)

Another serious burden is that a very large group of people respond to the constant uncertainty caused by the problems with regular alcohol consumption. Alcoholism is reported to be an everyday phenomenon and has become accepted in the settlements investigated. According to the interviewees, it works as a "selfdefence mechanism", which serves to alleviate the psychological burden and solves the fear from everyday difficulties and vulnerability.

\section{Conclusions}

Our study aims to demonstrate the standard of living of the Hungarians in Ukraine, especially with regard to the poverty of families with children. In our introduction, Hungarians in Ukraine are presented on the basis of available statistics and census data, giving attention to the socio-demographic, fundamental economic, social, and political characteristics of the region and to the peripheral labour market situation thereof. So far, there has not been conducted any systematic research in the region on the measurement of poverty. Thus, our investigation was primarily an exploratory study with the aim of identifying the poverty of households with children. We worked with both quantitative and qualitative methods where we encountered difficulties due to the lack of data in the region or the complete lack of reliable statistical records. These were addressed by region-specific solutions, what is explained in detail in the methodological section. In the questionnaire study, we examined 139 households and 253 children, while during the qualitative procedure 23 exploratory interviews were made.

The lack of basic infrastructural facilities of the examined settlements determined the comfort level of housing and housing poverty. The partial absence of natural gas and drinking water or the complete lack of drainage and waste management do 
not create the opportunity for a life without deprivation. In families with children, the average number of children is 2 , but people typically live in extended family forms, primarily because of the better allocation of costs. Household poverty was mostly perceived by our deprivation attributes. According to the deprivation index, half of the families with children live in poverty, and nearly three-quarters of these families can be classified into the category of the seriously deprived.

In the examined area, atypical employment possibilities have become typical. There are few employers in the region, and the jobs they offer can usually be filled by speakers of Ukrainian. Because of the lack of job possibilities in the region, the level of education has no detectable effect on the employment of the workforce even among those with a higher level of education. Seemingly, commuting could mean a way out, an alternative, similarly to foreign employment, which male members of families sometimes choose as their life strategy.

We typified the forms of work and measured the labour intensity of households. There is a very low employment level in the households surveyed, and the distribution of work among the households is very uneven. We distinguished between those who are officially registered as employed, those who are engaged in occasional work, and those with other alternative earning solutions. A quarter of the households were almost completely excluded from the labour market, and this brought about strategies such as the sale of seasonal products, metal collection on landfills, cross-border livelihood activities, or the usurious scheme.

In our study, we provided a brief insight into the marginal living conditions of the Hungarian households with children, living in minority in Ukraine, into the rural everyday life of the closed and isolated population, and into the characteristics of the constraints of life forms brought about by the lack of social security.

\section{References}

Baranyi, Béla, Balcsók, István. 2004. Határmenti együttmúködés és a foglalkoztatás kelet-magyarországi helyzetképe [Cross-Border Co-operation and Employment Situation Report in Eastern Hungary]. Budapest: Magyar Tudományos Akadémia Közgazdaságtudományi Intézet.

Braun, László, Csernicskó, István, Molnár, József. 2010. Magyar anyanyelvú cigányok/romák Kárpátalján [Gypsies/Gypsies with Hungarian Mother Tongue in Transcarpathia]. Ungvár: II. Rákóczi Ferenc Kárpátaljai Magyar Főiskola.

Central Intelligence Agency. 2010. The World Factbook. (https://www.cia.gov/ library/publications/the-world-factbook).

Csepeli, György, Kolosi, Tamás, Neményi, Mária, Örkény, Antal. 1992. A gazdagság és a szegénység okaira adott magyarázatok rejtett normatív szempontjai 
Magyarországon [Latent Normative Perspectives in the Explanations for Poverty and Wealth in Hungary]. Szociológiai Szemle 3: 21-41.

Czibere, Ibolya, Loncsák, Noémi. 2018. A falvakban élő gyermekes háztartások helyzete Kárpátalján [How Households with Children Live in the Transcarpathian Countryside]. Metszetek 7(2): 53-71. DOI: 10.18392/metsz/2018/2/4.

Czibere, Ibolya, Loncsák, Noémi, Gégény, János (eds.). 2017. Átlagosan élünk. A kárpátaljai magyarság gyermekes háztartásainak életkörülményei [Our Average Standard of Living. Study among Households with Children in Hungarian Transcarpathian Villages]. Debrecen: University of Debrecen Press.

Darcsi, Karolina. 2008. A 2006-os ukrajnai választások és a kárpátaljai magyarság [The 2006 Ukrainian Elections and Subcarpathian Hungarians]. In: Soós, K. (ed.), A II. Rákóczi Ferenc Kárpátaljai Magyar Fóiskola Lehoczky Tivadar Intézetének tanulmánygyújteménye. Ungvár: Poliprint. 63-68.

Egészségügyi Stratégiai Kutatóintézet. 2005. Tájékoztató országtanulmány. Ukrajna [Informative Country Study. Ukraine]. Budapest: ESKI Egészségügyi Rendszertudományi Irodája.

Esping-Andersen, Gosta. 2008. Egy gyermekközpontú társadalmi beruházási stratégia [A Child-Centred Social Investment Strategy]. Esély 5: 28-70.

Európai Bizottság. 2010. EURÓPA 2020. Az intelligens, fenntartható és inkluzív növekedés stratégiája [The Strategy of Smart, Sustainable and Inclusive Growth]. (http://ec.europa.eu/eu2020/pdf/1_HU_ACT_part1_v1.pdf) (last downloaded on: 2018.04.19).

Gyémánt, Richárd. 2011. A határon túli magyarság demográfiai és társadalomstatisztikai sajátosságai [Demographic and Social Statistics of the Hungarians beyond the Borders]. PhD thesis. Szeged: University of Szeged.

Kovály, Katalin, Erőss, Ágnes, Tátrai, Patrik. 2017. „Hát megpróbálunk küzdeni”: átalakuló boldogulási stratégiák Kárpátalján az Euromajdan után ["So, We Try to Fight”: Livelihood Strategies in Transition after the Euromaidan in Transcarpathia, Ukraine]. Tér és Társadalom 31(2): 3-22.

KSH. 2016. A háztartások életszínvonala, 2016.

(https://www.ksh.hu/docs/hun/xftp/idoszaki/hazteletszinv/hazteletszinv16. pdf) (last downloaded on: 2018.04.20).

Loncsák, Noémi. 2015. Szegénységi lét az ukrajnai magyarság körében [Poverty among the Hungarians in Ukraine]. In: Dobi, E. (ed.), Juvenilia VI. Debreceni bölcsész diákkörösök antológiája. Debrecen: Printart-Press Kft.

Molnár, Eleonóra, Orosz, Ildikó. 2007. Kárpátalja (Ukrajna). In: Papp, Z. Attila, Veres, Valér (eds.), Kárpát Panel 2007. A Kárpát-medencei magyarok társadalmi helyzete és perspektívái. Budapest: MTA Etnikai-Nemzeti Kisebbségkutató Intézet.

Molnár, József, Molnár, D. István. 2005. Kárpátalja népessége és magyarsága a népszámlálási és népmozgalmi adatok tükrében [The Population and the 
Hungarians of Transcarpathia in the Light of the Census and Population Movement Data]. Beregszász: Kárpátaljai Magyar Pedagógusszövetség Tankönyvés Taneszköztanácsa.

Sik, Endre. 2015. Adalékok a hármashatár háromszoros beágyazottságához [Additions to the Threefold Embedding of the Triple Border]. In: Sik, E., Surányi, R. (eds.), Határhatások. Budapest: Eötvös Loránd Tudományegyetem, Társadalomtudományi Kar (ELTE TáTK)-Társadalomkutatási Intézet Zrt. (TÁRKI). 34-94.

Silver, Hilary. 1996. Culture, Politics and National Discourse of the New Urban Poor. In: Mingione, Enzo (ed.), Urban Poverty and the Underclass. Oxford-Cambridge: Blackvell Publishers. 3-40.

Szalai, Júlia. 2002. A társadalmi kirekesztődés egyes kérdései az ezredforduló Magyarországán. [Some Questions in Social Exclusion at the Turn of the Century in Hungary]. Szociológiai Szemle 4: 34-50.

Tátrai, Patrik, Molnár, József, Kovály, Katalin, Erôss, Ágnes. 2018. A kárpátaljai magyarok lélekszáma és a népesedésüket befolyásoló tényezők a SUMMA 2017 felmérés alapján [The Hungarian Transcarpathian Population and Factors That Impact Their Population Trends, Based on SUMMA 2017 Survey Results]. Kisebbségi Szemle 3: 7-31. 